\title{
Everolimus: a review of its pharmacologic properties and use in solid organ transplantation
}

Paul Huiras ${ }^{1}$, Steven Gabardi ${ }^{2-5}$

Department of Pharmacy Services, Beth Israel Deaconess Medical Center, Boston, MA

Department of Pharmacy Services, Brigham and Women's Hospital, Boston, MA

Department of Transplant Surgery, Brigham and Women's Hospital, Boston, MA

Renal Division, Brigham and Women's Hospital, Boston, MA

5 Department of Medicine, Harvard Medical School, Boston, MA

\section{Abstract}

The aim of this review article is to review the pharmacology, pharmacokinetics, efficacy and safety of everolimus. Primary literature was obtained via MEDLINE. Studies and abstracts evaluating everolimus in solid organ transplantation were considered for evaluation. English-language studies and abstracts only were selected for inclusion. Everolimus, a proliferation signal inhibitor that prevents growth factor-induced cell proliferation, is effective in reducing the incidence of acute rejection in solid organ transplantation. This agent is also useful in reducing cyclosporine-related nephrotoxicity. Everolimus directly inhibits vascular remodelling and intimal thickening, which are often associated with chronic rejection. Clinical trials have shown that everolimus is generally safe. The most commonly reported adverse events were haematologic effects and hyperlipidaemia. Everolimus is the second proliferation signal inhibitor to be proven effective in preventing acute rejection in solid organ transplant recipients. However, its exact role in the transplant immunosuppressive armamentarium is still unknown.

\section{Keywords}

Everolimus; mToR inhibitor; Immunosuppressant; Renal transplant; Heart transplant; Solid organ transplant 


\section{Background}

Advances in the field of immunology have led to the discovery of new intracellular targets for immunosuppression. The mammalian target of rapamycin (mToR), or FK binding protein-12 (FKBP12)rapamycin-associated-protein pathway, represents one of these. This large protein kinase is an intracellular convergence point for several biologic processes that are essential for cellular metabolism and proliferation [1]. Everolimus, like sirolimus, reversibly binds and activates cytoplasmic FKBP12. Once activated, growth factor-stimulated phosphorylation of p70 S6 kinase, a key enzyme in protein synthesis, is inhibited and the cell cycle is arrested at the late G1 stage [1]. Therefore stimulatory hormonal and cytokine (interleukin-2 [IL-2], interleukin-15 [IL-15]) mediated proliferation is inhibited, providing the basis for everolimus activity in preventing T-cell mediated allograft rejection [1-5]. Everolimus has proven to be a useful agent in oncology and cardiology, but this review will focus on its application in transplant. The pharmacodynamic, pharmacokinetic, dosing, drug-drug interaction and adverse event profiles of everolimus will be reviewed first, followed by a brief summary of the literature supporting its use in solid organ transplant (SOT).

\section{Data source}

A non-date restricted MEDLINE search was conducted for English-language articles using the terms everolimus, RAD, RAD001, SDZ RAD, Afinitor, Certican, Xience and Zortress. Data were available from July 1997 to July 2011. Selection focused on human pharmacology, pharmacokinetics and clinical data for transplantation only. Only data from fully published studies were included.

\section{Chemistry and pharmacodynamics}

Everolimus is a macrolide derivative in which a 2-hydroxyethyl group has been introduced in position 40 (40-O-(hydroxyethyl)-rapamycin) (Figure 1) [6]. This alkalation at the C40 position is what chemi-

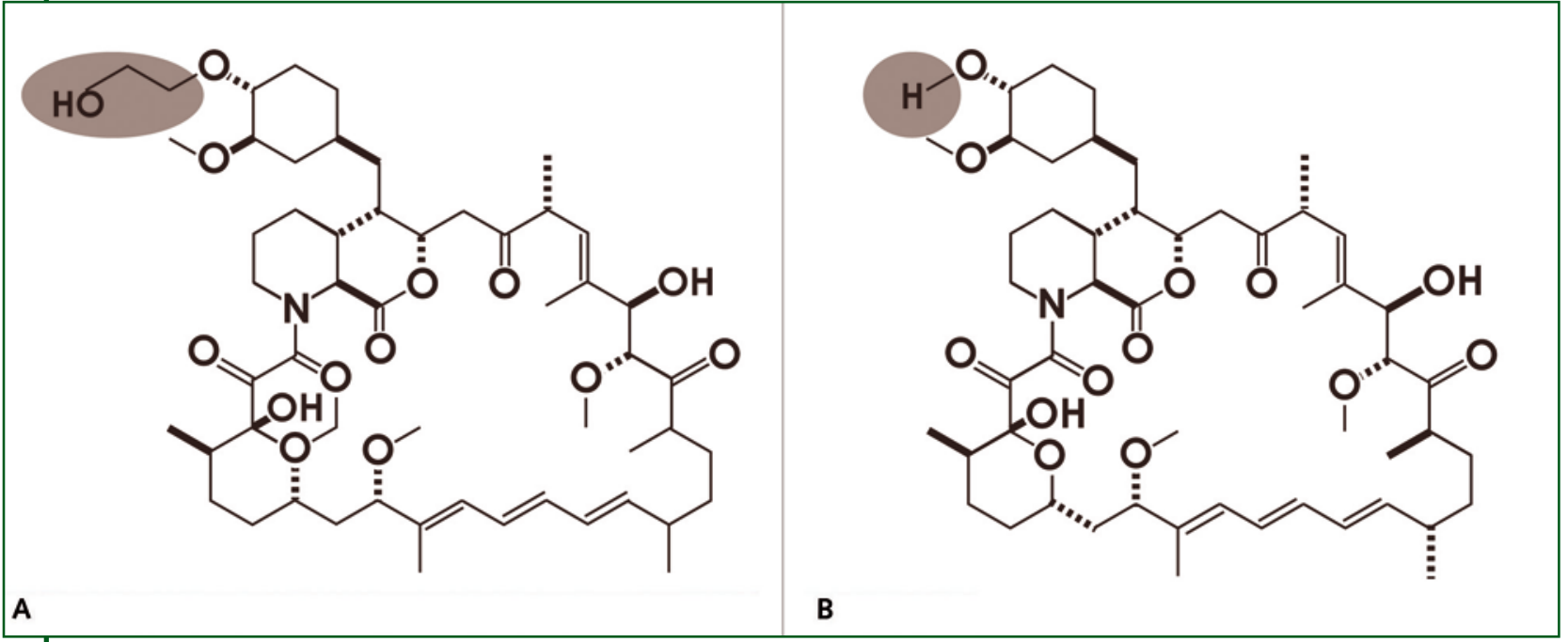

Figure 1. Chemical structures of everolimus and sirolimus $\mathrm{A}=$ everolimus; $\mathrm{B}=$ sirolimus 
cally distinguishes everolimus from sirolimus. Pharmacodynamically, it weakens the affinity of everolimus for the FKBP12 protein complex [7]. Clinically, this difference is of little consequence [7].

\title{
Pharmacokinetics
}

\begin{abstract}
Absorption/distribution
Similar to its predecessor, everolimus is a substrate of P-glycoprotein (P-gp), a drug transport protein, which significantly impacts its bioavailability. Of the two agents, everolimus has a lower bioavailability $(14 \%$ versus $20 \%)[8,9]$. Peak drug concentration $\left(\mathrm{C}_{\max }\right)$ occurs within one to two hours, following an oral dose [8,10]. Everolimus has a large volume of distribution at $342 \pm 1071$ (range 128-589 1) [8]. It is highly bound to circulating red blood cells and plasma proteins $[8,10]$. Linear pharmacokinetics are observed with this agent and blood concentrations vary from 0.25 to $15 \mathrm{mg} / \mathrm{dose}$ [11-13]. The oral absorption of this medication is significantly delayed in the presence of concomitant fat ingestions resulting in a diminished $\mathrm{C}_{\max }$ and the overall exposure (AUC) of everolimus [14]. Patients should be advised to take this medication consistently with or without food.
\end{abstract}

\section{Metabolism/excretion}

Everolimus is metabolized via CYP3A4 isoenzymes to inactive metabolites $[8,15]$. The half-life ranges 18-35 hours with only a small fraction, less than $10 \%$, of the drug being excreted unchanged in the urine [15]. Since it is primarily metabolized via the liver, hepatic impairment (Child-Pugh class B) may increase the $t_{1 / 2}$ and dose adjustment may be necessary.

\section{Dosing and therapeutic drug monitoring}

For renal and cardiac transplant populations, patients are initiated on an oral dosing regimen of 0.75 $\mathrm{mg}$ twice daily or $1.5 \mathrm{mg} /$ day [5]. Doses are adjusted based on whole blood drug concentration monitoring $[16,17]$. The therapeutic efficacy and toxicity of everolimus are concentration dependent with a moderate amount of inter-patient variability [16-18]. Therapeutic drug monitoring (TDM) is very useful and is recommended in SOT recipients. Generally, concentrations of $>3 \mathrm{ng} / \mathrm{ml}$ are desirable when given with a CNI (Calcineurin Inhibitor) and trough levels $>8 \mathrm{ng} / \mathrm{ml}$ have been associated with increased toxicity $[16,17]$. Higher target levels $(6-10 \mathrm{ng} / \mathrm{ml})$ may be necessary to maintain efficacy with CNI withdrawal regimens.

\section{Drug-drug interactions}

Everolimus is a substrate of the CYP3A4 isoenzyme and, therefore, powerful inhibitors, inducers, and other CYP3A4 substrates may affect everolimus concentrations. Conversely, everolimus may affect concentrations of other CYP3A4 substrates. CNIs, which are often used concomitantly in SOT, are 3A4 substrates and thus these drug-drug interactions are well described [19].

Azole antifungals and macrolide antibiotics, known CYP3A4 inhibitors, significantly increase concentrations of everolimus to varying degrees. Ketaconazole given concomitantly can nearly quadruple everolimus $\mathrm{C}_{\max }$ when given to health volunteers $(15 \pm 4 \mathrm{ng} / \mathrm{ml}$ to $59 \pm 13 \mathrm{ng} / \mathrm{ml})$ [20]. Itraconazaole has been shown to reduce everolimus clearance by as much as $74 \%$ [19]. While macrolides, such as erythromycin and azithromycin, can decrease everolimus clearance up to $22 \%$ [19]. 
Conversely, rifampin, a known CYP3A4 inducer, has been shown to significantly increase the clearance of everolimus. In a pharmacokinetic study by Kovarik et al., the half-life of everolimus was shortened, on average, from 32 to 24 hours ( $\mathrm{p}=0.0001)$ and the $\mathrm{C}_{\max }$ of everolimus decreased by $58 \%(\mathrm{p}=0.0001)$ [21]. Concomitant use of these two agents warrants close monitoring of everolimus levels.

Atorvastatin and pravastatin have been studied for their potential to influence the pharmacokinetics of everolimus [22]. These agents, which are often given concomitantly with everolimus to treat mToRinduced hyperlipidaemia, were found to have no clinically significant effect on everolimus concentrations [22].

Cyclosporine (CsA) is both a substrate and a mild inhibitor of CYP3A4. As such, it has the potential to increase everolimus exposure when given in combination. This effect was found to be dependent up the formulation of cyclosporine used in combination with everolimus [23]. Kovarik et al. found that only co-administered CsA-modified was found to increase $\mathrm{C}_{\max }$ concentrations of everolimus statistically ( $82 \%, \mathrm{p}=0.0001)$ while conventional CsA had little effect on this kinetic parameter $(6 \%, \mathrm{p}=\mathrm{ns})$. In contrast, everolimus has been found to have little effect on CsA pharmacokinetics [23].

Tacrolimus, also a substrate of CYP3A4, is affected by concomitant everolimus administration. A study conducted by Pascual et al. compared tacrolimus pharmacokinetics among patients randomized to receive everolimus at dose of either 1.5 or $3 \mathrm{mg} /$ day along with corticosteroids and tacrolimus [24]. Even though patients in the $3 \mathrm{mg} /$ day everolimus group received larger daily tacrolimus doses, mean tacrolimus $\mathrm{C}_{\min }$ was higher than the $1.5 \mathrm{mg} /$ day everolimus group $(11.1 \mathrm{vs.} 9.4, \mathrm{p}=0.03$ ). This drugdrug interaction did not affect clinical outcomes in this study, but practitioners should be mindful that everolimus will affect tacrolimus levels.

\section{Adverse effects}

The therapeutic efficacy of everolimus hinges on its ability to affect multiple cytokine and hormone driven pathways. Unfortunately, this nonspecific interruption of cellular signalling also accounts for many of the side effects seen with mToR inhibitors.

Delayed wound healing and delayed graft function (DGF) are two adverse effects that have been associated with mToR inhibitor use. Following transplant multiple growth factors (vascular endothelial growth factors, platelet-derived growth factor, epidermal growth factor) may quicken healing. These growth factors require functional mToR enzymes for optimal signal transduction and sirolimus use, in particular, has been associated with anastomotic dehiscence in lung transplant when used immediately posttransplant $[25,26]$. The need for caution with everolimus especially in other types of transplantation, is less clear. In a prospective, multicenter, open-label study by Albano et al., renal transplant recipients (RTR) were randomized to receive everolimus immediately or delayed until five weeks post-transplant [27]. All patients were given anti-IL-2 antibodies for induction and maintained on CsA, corticosteroids. In addition to these agents, the delayed everolimus group received mycophenolate mofetil (MMF) until the conversion to everolimus. No difference was seen in delayed wound healing events in the immediate versus the delayed everolimus group ( $40 \%$ vs. $41.9 \%, \mathrm{p}=\mathrm{ns}$ ). Similarly the rates of DGF were nearly identical in the immediate and delayed groups $24.6 \%$ and $24.3 \%(\mathrm{p}=\mathrm{ns})$. Studies such as this call into question whether everolimus clinically effects wound healing and delay graft function [27].

Cytomegalovirus (CMV) induced disease is a complication of overall immunosuppression. However, the rates of CMV seroconversion, viraemia and disease may be lower in patients given everolimus when compared to other immunosuppressive regimens $[6,28,29]$.

Lipid disturbances, especially hyperlipidaemia, are well described following at least two to three weeks of everolimus therapy post transplant. Often medications to lower serum lipids are necessary especially in both cardiac and renal transplant patients. Other reported side effects include mouth ulcers, nausea/ 
vomiting, headache, elevated transaminases, diabetes, skin lesions, pneumonitis, and a concentration dependent myelosuppression [30].

Lastly, while everolimus causes no direct nephrotoxic effects, its use was originally associated with increases in serum creatinine compared to other anti-metabolites. In many of the initial studies decreases in renal dysfunction were thought to be due to the previously described drug-drug interaction between CsA modified and everolimus, resulting in higher CsA exposure. When CsA doses were adjusted appropriately for this interaction based on CsA levels, renal function improved [28,31-34].

\section{Clinical efficacy in solid organ transplant}

Everolimus is approved for prevention of rejection in organ transplant recipients in over 70 countries worldwide and its use is supported by many published, peer-reviewed trials on everolimus, which will be presented below. The majority of published trials with everolimus in SOT were in kidney and heart transplant. This is not surprising since everolimus reduces smooth muscle cell proliferation and prevent remodelling, both of which are advantageous in preventing chronic allograft nephropathy (CAN), seen in kidney transplant, and cardiac allograft vasculopathy (CAV), a known complication of heart transplant. Everolimus has also been studied in lung and liver transplant.

\section{Kidney transplant}

In the first phase II clinical trials examining the efficacy of this novel mToR inhibitor, everolimus was given in lieu of other antimetabolites such as mycophenolate or azathioprine (AZA). In one of the earliest phase II clinical trials published in 2002, everolimus was given in addition to tacrolimus at different doses [35]. In this prospective, six-month, multicenter, open-label study, all patients received induction with basiliximab and were maintained on corticosteroids and everolimus (dosed to trough levels: $\geq 3 \mathrm{ng} / \mathrm{ml}$ and $<12 \mathrm{ng} / \mathrm{ml}$ ). Patients were divided into two groups: low dose tacrolimus (target trough levels: 4 to $7 \mathrm{ng} / \mathrm{ml}$ from day 1 to month 3, and 3 to $6 \mathrm{ng} / \mathrm{ml}$ from months 4 to 6) or standard dose tacrolimus (target trough levels: 8 to $11 \mathrm{ng} / \mathrm{ml}$ from months 1 to 3 , and 7 to $10 \mathrm{ng} / \mathrm{ml}$ from months 4 to 6). Biopsy proven acute rejection (BPAR) was evaluated at 6 months and found to be $14 \%$ in both groups. With efficacy being identical, this study began building a case for using everolimus as a means to decrease CNI exposure in RTR [35].

A very similar second phase II study (B156) was published in 2004 and evaluated everolimus and various levels of CsA exposure [33]. This again was a randomized, open label study but evaluated patients for three years. Similarly patients were induced with basiliximab and maintained on corticosteroids, however, the everolimus dose was fixed at $3 \mathrm{mg} /$ day. Patients were randomized to receive either low dose CsA targeting a trough of 50 to $100 \mathrm{ng} / \mathrm{ml}$ or full-dose CsA targeting troughs of $125-250 \mathrm{ng} / \mathrm{ml}$. Efficacy failure was measured via the composite endpoint of BPAR, graft loss, death, or loss to followup at 6, 12 and 36 months. Statistically less patients experienced efficacy failure in the low dose CsA group at 6 months $(3.4 \%$ vs. $15.1 \%, \mathrm{p}=0.046), 12$ months $(8.6 \%$ vs. $28.3, \mathrm{p}=0.012)$ and 36 months $(17.2 \%$ vs. $35.8, \mathrm{p}=0.032)$. Mean creatinine clearance rates were also higher in the low dose CsA group at 6 and 12 months. These results provided more strength to the argument that everolimus coupled to low dose CNI may lead better clinical efficacy with short-term preserved renal function [33].

Two phase III clinical trials (B201 and B251) published in 2005 evaluated everolimus at different doses ( $1.5 \mathrm{mg} /$ day versus $3.0 \mathrm{mg} /$ day) compared to immunosuppressive regimens containing mycophenolate. All patient received corticosteroids, and full dose CsA in these trials [31,32]. These studies were prospective, multicenter, with parallel group design and follow up to 3 years. Both were blinded up to 1 year, at which time open label use of everolimus was allowed. A composite endpoint was again used and included biopsy-proven acute rejection (BPAR), graft loss, death, or loss to follow-up. No differences 
in the composite endpoint were seen between the high and low dose everolimus groups in throughout both studies. The authors concluded that both doses were equally efficacious, however some safety concerns were raised regarding the use of high dose CsA and the higher dose of everolimus [31,32].

In these studies, the protocol for blinding everolimus use was amended at one year specifically for concerns of nephrotoxicity with everolimus use. In those with nephrotoxicity, everolimus doses were titrated to levels $<3 \mathrm{ng} / \mathrm{ml}$ which halted serum creatinine increases. In both of these trials patients were receiving CsA-modified, which interacts with everolimus kinetically. It is important to note that when CsA levels were reduced renal function also improved, suggesting that TDM is necessary for both mToR and CNIs when used in combination.

In the light of the preliminary findings of increased renal dysfunction, two phase IIIb studies (A2306/2307) were conducted to determine the optimal CsA exposure to produce target efficacy while avoiding nephrotoxicity [36]. A similar design was used in these trials, however, patients in the A2306 trial received basiliximab for induction. Everolimus was given at a dose of either $1.5 \mathrm{or} 3 \mathrm{mg} /$ day (adjusted to troughs of $>3 \mathrm{ng} / \mathrm{ml}$ ) and patients were maintained on corticosteroids and low-dose CsA. In trial A2306, in patients that received basiliximab, the target CsA concentrations measured 2 hours post-dose (CSA C2) were 500 to $700 \mathrm{ng} / \mathrm{ml}$ for weeks 0 to 8 and 350 to $450 \mathrm{ng} / \mathrm{ml}$ thereafter. In the other study A2306, CsA C2 targets were between 1000 to $1400 \mathrm{ng} / \mathrm{ml}$ for weeks 0 to 4,700 to 900 $\mathrm{ng} / \mathrm{ml}$ for weeks 5 to 8,550 to $650 \mathrm{ng} / \mathrm{ml}$ for weeks 9 to 12 and 350 to $450 \mathrm{ng} / \mathrm{ml}$ thereafter. The CsA $\mathrm{C} 2$ ranges in both of these trials represent lower than standard target ranges. The primary efficacy endpoint of renal function at 12 months was improved from the prior phase III trials (B251 and B201) with no increase in the secondary endpoint of efficacy failure compared to these earlier trials. When the individual components of the primary outcome were dissected, more BPAR was seen with everolimus $1.5 \mathrm{mg} /$ day in Study A2306 (25.0\%) than in Study A2307 (13.7\%). Because of this finding, it is though that anti-IL-2 receptor induction therapy may be beneficial in reducing the risk of early BPAR when used with a lower dose of everolimus. Combining data from all four of these phase III trials allowed authors to conclude that dosing everolimus to appropriate concentrations allows for the reduction of CsA concentrations without any significant detriment to efficacy or safety. This conclusion was most strongly supported in comparing data from Studies B201 (full-exposure CsA) and A2306 (reducedexposure CsA) which showed no difference in efficacy failure or renal function when CsA exposure was by $57 \%$ at 12 months. A recently published trial in 2010 by Tedesco Silva et al. verified that CsA exposure can be reduced by as much as $60 \%$ in patients treated with everolimus with no difference in outcomes compared to full dose CsA and mycophenolate [37].

Confirmation of the safety of everolimus when dose adjusted has led investigators to push the limits of traditional renal transplant pharmacotherapeutics and attempt to remove CNIs completely. Budde et al. recently published one of the largest multicenter open-label controlled trials evaluating CNI withdrawal in RTR (The Zeus Trial) [38]. All patients were induced with basiliximab and maintained immediately post transplant on corticosteroids, mycophenolate sodium, and CsA based on trough concentration. At 4.5 months post transplant those randomized to be converted to everolimus based regimens received $1.5 \mathrm{mg} /$ day titrated to a target trough concentration in conjunction with de-escalation of CsA concentrations in a stepwise fashion. CsA levels were titrated to $50 \%$ of standard concentrations in step 1, 25\% of goal in step 2 and $0 \%$ in step 3, which occurred over 4 weeks or less. Everolimus target levels in step 1 were 3 to $8 \mathrm{ng} / \mathrm{ml}$ and 6 to $10 \mathrm{ng} / \mathrm{ml}$ thereafter. At 12 months patients converted to everolimus had significantly higher glomerular filtration rates (GFR) versus those continued on CsA $(71.8 \%$ vs. $61.9 \%, \mathrm{p}<0.001)$. Rates of BPAR were similar to $15 \%$ for both groups at 12 months. Consistent with other trials, higher mean lipid concentrations, urinary protein excretion and lower haemoglobin values were seen in the everolimus group [38]. Overall the results of trials such as these in RTR has bolstered the interest of using everolimus in other types of organ transplant especially in cases where CNIs are not well tolerated.

The main trials about the use of everolimus in renal transplantation are summarized in Table I. 


\begin{tabular}{|c|c|c|c|c|c|}
\hline $\begin{array}{l}\text { 1st Author } \\
\text { [Study] }\end{array}$ & Year & No. pts. & Intervention & Outcome & Conclusions \\
\hline $\begin{array}{l}\text { Chan } \\
\text { (US09) [35] }\end{array}$ & 2002 & 92 & $\begin{array}{l}\text { Low dose tacrolimus versus } \\
\text { standard dose tacrolimus } \\
\text { in patients induced with } \\
\text { basiliximab receiving } \\
\text { everolimus (targeted to troughs } \\
>3 \mathrm{ng} / \mathrm{ml} \text { ) and corticosteroids }\end{array}$ & $\begin{array}{l}\text { No difference in BPAR in either } \\
\text { low or high dose group at } 6 \\
\text { months }\end{array}$ & $\begin{array}{l}\text { Everolimus and low dose } \\
\text { tacrolimus is efficacious in } \\
\text { RTR }\end{array}$ \\
\hline $\begin{array}{l}\text { Nashan } \\
\text { (B126) [33] }\end{array}$ & 2004 & 111 & $\begin{array}{l}\text { Low dose CsA versus standard } \\
\text { dose CsA in patients induced } \\
\text { with basiliximab and receiving } \\
\text { everolimus } 3 \mathrm{mg} / \text { day and } \\
\text { corticosteroids }\end{array}$ & $\begin{array}{l}\text { The composite endpoint of BPAR, } \\
\text { graft loss, death, or loss to follow- } \\
\text { up was statistically lower at } 6,12 \text {, } \\
\text { and } 36 \text { months in the low dose } \\
\text { CsA group. Creatinine clearance } \\
\text { was also lower in the low dose } \\
\text { CsA group }\end{array}$ & $\begin{array}{l}\text { Everolimus and low dose } \\
\text { CsA maybe more effective } \\
\text { and less toxic than } \\
\text { everolimus and standard } \\
\text { dose CsA }\end{array}$ \\
\hline $\begin{array}{l}\text { Vitko (B201) } \\
\text { [31] }\end{array}$ & 2005 & 588 & $\begin{array}{l}\text { Everolimus } 1.5 \mathrm{mg} \text { or } 3 \mathrm{mg} / \\
\text { day compared to MMF in } \\
\text { patients receiving standard } \\
\text { dose CsA and corticosteroids }\end{array}$ & $\begin{array}{l}\text { No difference in BPAR, graft } \\
\text { loss, death or loss to follow-up } \\
\text { in either of the groups. Serum } \\
\text { creatine was lower in the MMF } \\
\text { group }\end{array}$ & $\begin{array}{l}\text { Both doses of everolimus } \\
\text { were efficacious, but renal } \\
\text { toxicity in conjunction with } \\
\text { full dose CsA remains a } \\
\text { concern }\end{array}$ \\
\hline $\begin{array}{l}\text { Vitko } \\
\text { (A2306) [36] }\end{array}$ & 2004 & 237 & $\begin{array}{l}\text { Everolimus } 1.5 \text { versus } 3 \\
\mathrm{mg} / \text { day (both adjusted to } \\
\text { troughs }>3 \mathrm{ng} / \mathrm{ml} \text { ) in patients } \\
\text { receiving CsA (adjusted to } \\
\text { lower than standard trough } \\
\text { values) and corticosteroids }\end{array}$ & $\begin{array}{l}\text { No difference in renal function } \\
\text { was seen between the two doses } \\
\text { of everolimus. No difference } \\
\text { in BPAR, graft loss or death } \\
\text { between the two groups }\end{array}$ & $\begin{array}{l}\text { Concentration adjusted } \\
\text { everolimus coupled to } \\
\text { concentration controlled } \\
\text { CsA results in acceptable } \\
\text { efficacy without excessive } \\
\text { nephrotoxity }\end{array}$ \\
\hline $\begin{array}{l}\text { Vitko } \\
(\mathrm{A} 2307) \\
{[36]}\end{array}$ & 2004 & 256 & $\begin{array}{l}\text { Everolimus } 1.5 \text { versus } 3 \mathrm{mg} \text { / } \\
\text { day (adjusted to troughs }> \\
3 \mathrm{ng} / \mathrm{ml} \text { ) in patients induced } \\
\text { with basiliximab and receiving } \\
\mathrm{CsA} \text { (adjusted to lower than } \\
\text { standard trough values) and } \\
\text { corticosteroids }\end{array}$ & $\begin{array}{l}\text { No difference in renal function } \\
\text { was seen between the two doses } \\
\text { of everolimus. No difference in } \\
\text { BPAR, graft loss or death between } \\
\text { the two groups. However less } \\
\text { BPAR was seen in the everolimus } \\
1.5 \mathrm{mg} / \text { day group in this study } \\
\text { compared to the prior study in } \\
\text { the } 1.5 \mathrm{mg} \text { /day group }\end{array}$ & $\begin{array}{l}\text { Concentration adjusted } \\
\text { everolimus coupled to } \\
\text { concentration controlled } \\
\text { CsA results in acceptable } \\
\text { efficacy without excessive } \\
\text { nephrotoxity. When using } \\
\text { low dose everolimus } \\
\text { basiliximab induction may } \\
\text { help prevent BPAR }\end{array}$ \\
\hline $\begin{array}{l}\text { Lorber } \\
\text { (B251) [32] }\end{array}$ & 2005 & 583 & $\begin{array}{l}\text { Everolimus } 1.5 \text { or } \\
3 \mathrm{mg} / \text { day compared to } \mathrm{MMF} \\
2 \mathrm{~g} / \text { day in patients receiving } \\
\text { standard dose CsA and } \\
\text { corticosteroids }\end{array}$ & $\begin{array}{l}\text { No difference in the composite } \\
\text { endpoint of biopsy-proven acute } \\
\text { rejection, graft loss, death, or loss } \\
\text { to follow-up between the two } \\
\text { groups. Serum creatinine was } \\
\text { lower in the MMF group }\end{array}$ & $\begin{array}{l}\text { Both doses of everolimus } \\
\text { ( } 1.5 \text { or } 3 \mathrm{mg} / \text { day) were } \\
\text { efficacious, but higher } \\
\text { doses may have resulted } \\
\text { in a higher incidence in } \\
\text { nephrotoxicity compared } \\
\text { to MMF. Combined use } \\
\text { with CsA requires dose } \\
\text { adjustments of CsA and } \\
\text { everolimus to limit toxicity }\end{array}$ \\
\hline $\begin{array}{l}\text { Budde } \\
\text { (Zues) [38] }\end{array}$ & 2010 & 503 & $\begin{array}{l}\text { Conversion of CsA based } \\
\text { regimen to everolimus based } \\
\text { at } 4.5 \text { months post transplant }\end{array}$ & $\begin{array}{l}\text { Everolimus conversion was } \\
\text { associated with a significant } \\
\text { improvement in GFR at } 6 \\
\text { months, but not at } 12 \text { months } \\
\text { post transplant. No difference } \\
\text { in BPAR was seen at } 12 \text { month } \\
\text { between the two groups }\end{array}$ & $\begin{array}{l}\text { Everolimus conversion } \\
\text { therapy in RTR is safe and } \\
\text { efficacious }\end{array}$ \\
\hline
\end{tabular}

Table I. Review of selected literature in renal transplantation

$\mathrm{BPAR}=$ biopsy proven acute rejection; $\mathrm{Cs}$ = cyclosporine; $\mathrm{GFR}=$ glomerular filtration rate; $\mathrm{MMF}=$ mycophenolate mofetil; RTR = renal transplant recipients 


\section{Heart transplant}

Similar to the progression seen in kidney transplant, everolimus was first studied in place of antimetabolites in heart transplantation $[28,39,40]$. While CNI reduction and removal with everolimus use in this population have been promising, it has yet to be assessed in a randomized controlled fashion [41,42].

A large randomized controlled trial of over 600 patients was conducted by Eisen et al. in heart transplant recipients comparing everolimus to AZA [28]. All patients were maintained on CsA and corticosteroids. Patients received everolimus at $1.5 \mathrm{mg} /$ day $(\mathrm{n}=209)$ or $3 \mathrm{mg} / \mathrm{day}(\mathrm{n}=211)$, or AZA at a dose of $1-3 \mathrm{mg} / \mathrm{kg} / \mathrm{day}$ of $(\mathrm{n}=214)$. The primary composite endpoint consisted of death, graft loss, retransplantation, lost to follow-up and biopsy proven acute rejection of grade $3 \mathrm{~A}$ or rejection with haemodynamic compromise seen within the first six months following transplantation. They were also assessed in a 24-month follow-up to this study [39]. More patients attained the primary endpoint at 6 months in the AZA group (46.7\%) compared to those receiving everolimus at either dose $(1.5 \mathrm{mg} /$ day $=36.4 \%, \mathrm{p}=0.03 ; 3 \mathrm{mg} / \mathrm{day}=27 \%, \mathrm{p}<0.001)$ [28]. The incidence of the composite endpoint remained lower at 24 months in patients treated with everolimus $(1.5 \mathrm{mg} /$ day $=45.9 \%, \mathrm{p}=0.016 ; 3 \mathrm{mg} / \mathrm{day}=$ $36 \%, \mathrm{p}<0.001)$ versus AZA (57.5\%) [39]. CAV was significantly lower with everolimus $(1.5 \mathrm{mg} /$ day $=$ $35.7 \%, \mathrm{p}=0.045 ; 3 \mathrm{mg} /$ day $=30.4 \%, \mathrm{p}=0.01)$ than with AZA (52.8\%) at 6 months [28]. However, at 24 months only the low dose everolimus group retained a statistical difference in rates of vasculopathy at $33.3 \%$ compared $58.3 \%$ with AZA ( $p=0.017)$ [39]. At 6 months everolimus use was associated with a decrease in CMV rates in both groups $(1.5 \mathrm{mg} / \mathrm{day}=7.7 \%, \mathrm{p}<0.001 ; 3 \mathrm{mg} /$ day $=7.6 \%, \mathrm{p}<0.001)$ compared to AZA (21.5\%). At 6 and at 24 months serum creatinine levels were significantly higher in the two everolimus compared to the AZA group, but decreased when CsA exposure was reduced. As in the early trials with everolimus and CsA combinations, renal dysfunction was attributed to higher CsA exposure. Not only did these trials establish the safety and efficacy of everolimus for heart transplant, but this agent proved to be effective in reducing CAV, a major contributor to late allograft failure and mortality [39].

Everolimus has also been studied prospectively in a randomized fashion compared to mycophenolate mofetil in heart transplant recipients [40]. While some patients received induction therapy and others did not, all patients were maintained on corticosteroids. Patients were randomized to be maintained on either everolimus titrated to a trough of 3 to $8 \mathrm{ng} / \mathrm{ml}$ with reduced-dose CsA versus MMF $3 \mathrm{~g} /$ day with full dose CsA. The primary endpoint was the effect of the two regimens on post-transplant renal function. All efficacy endpoints for everolimus were deemed non-inferior to MMF at 12 months posttransplant. Although calculated creatinine clearance was $6.9 \mathrm{ml} / \mathrm{min}$ lower with everolimus compared to MMF at 6 months, this difference decreased to only $3.1 \mathrm{ml} / \mathrm{min}$ by 12 months. Lower rates of CMV infections were seen in the everolimus group at $4.4 \%$ versus the MMF group $16.9 \%$ ( $\mathrm{p}=$ 0.01). Concentration-controlled everolimus with reduced-dose CsA was just as efficacious and safe as MMF administered concomitantly with standard-dose CsA following cardiac transplantation in this 12-month controlled trial [40].

\section{Liver transplant}

To evaluate the safety and tolerability Levy et al. compared everolimus at various doses in addition to CsA and corticosteroids in liver transplant recipients $(n=119)$ [43]. Patients were randomized to receive everolimus at $2 \mathrm{mg} /$ day, $4 \mathrm{mg} /$ day or placebo in a double-blind fashion. Those patients receiving $4 \mathrm{mg} /$ day had numerically higher adverse events, but statistically the percent of adverse events were similar between all groups. Numerically less episodes of acute rejections were seen with everolimus treatment, but again the differences did not attain statistical significance. This study confirmed that everolimus is safe to use in conjunction with CsA and corticosteroids in liver transplant [43]. 
Two CNI conversion studies have been conducted with everolimus in liver transplant recipients [44]. The smaller of the two $(n=10)$ conducted in patients with new or recurrent hepatocarcinomas posttransplant showed no case of acute rejection and an acceptable level of adverse events [44]. The larger trial $(n=40)$ included patients that had CNI intolerance such as nephrotoxicity, microangiopathy or peripheral neuropathy [34]. A successful outcome was documented as a conversion to monotherapy with $1.5 \mathrm{mg} /$ day within 4 weeks. Treatment failure was defined as the presence of continued use of a CNI, patient death, and graft loss. At 12 months $75 \%$ of patients were successfully converted over and the patient and graft survival was $100 \%$. Patients that were successfully converted to everolimus had improvement in calculated creatinine clearance compared to baseline $(p<0.0001)$ [34]. While these two trials highlight the usefulness of everolimus in rescue situations, they also provide insight into the potential of using everolimus based therapy in liver transplant.

\section{Lung transplant}

The efficacy of everolimus has been evaluated in one large $(n=213)$ randomized double blinded study by Snell et al. Only patients with stable allograft function were included [45]. All patients received CsA and corticosteroids while 101 patients were randomized to initiate everolimus $3 \mathrm{mg} /$ day and 112 patients remained on AZA. A composite endpoint of decline in forced expiratory volume in 1 second $\left(\mathrm{FEV}_{1}\right)$ of $>15 \%$ from baseline, graft loss, death or lost to follow-up was used as evidence of treatment failure. At twelve months treatment failure was seen in $21.8 \%$ of the everolimus patients versus $33.9 \%$ in the AZA patients $(\mathrm{p}=0.046)$. This difference was not significant at 24 months. Although not part of the composite endpoint, the percentage of patients experiencing acute rejection was statistically lower in the everolimus group throughout the trial. Everolimus use was associated with significantly more infections and adverse events such as hyperlipidemia and myelosuppression [45].

\section{Evidence in paediatrics}

A small analysis $(\mathrm{n}=19)$ of everolimus $1.6 \mathrm{mg} / \mathrm{m}^{2} /$ day was conducted de novo in paediatric RTR. Patients received everolimus, corticosteroids and CsA-modified for 6 months [46]. No deaths, graft losses or losses to follow-up were documented; however 16\% BPAR was seen within this time period. Eighteen of the 19 patients experienced an adverse event including hyperlipidemia, bacterial infections, and lymphocele formation. Kinetic analysis revealed that weight, body-surface area and weight were all positively correlated to everolimus clearance. This study provided some insight into the efficacy and dosing considerations in pediatric patients [46].

In hopes of stabilizing biopsy proven transplant nephropathy everolimus was evaluated in 13 pediatric patients [47]. After CsA reductions by $50 \%$ and discontinuation of all other immunosuppressants, everolimus therapy was initiated and titrated to a target concentration of 3 to $6 \mathrm{ng} / \mathrm{ml}$. In this small study, initiation of everolimus resulted in no cases BPAR, further decline in renal function or significant adverse events [47]. While these two analyses of pediatric patients are small unblinded and not randomized, they represent the reported outcomes with everolimus use in pediatric SOT.

\section{Conclusions}

Everolimus has a reduced half-life, poorer bioavailability, and binds less tightly to the FKBP12 binding complex compared to sirolimus. The influence of these pharmacokinetic and dynamic differences on efficacy is difficult to elucidate. What is known is everolimus reaches steady state quicker, exhibits line- 
ar pharmacokinetics, and TDM can be utilized to ensure the efficacy of this agent. The most common adverse reactions with this agent remain hyperlipidemia and myelosuppression.

The majority of literature published with everolimus for SOT is in kidney and heart transplantation. In these populations, everolimus decreased CAV and CAN, both of which are associated with poor graft function and increased mortality. Everolimus has been compared to both antimetabolite therapies

\section{Questions for further research}

- What is the role of everolimus when used in conjunction with tacrolimus?

- What is the long-term efficacy and safety of conversion from a CNI to everolimus in stable RTRs?

- What are the implications of using everolimus in extra-renal transplant recipients in order to spare renal function? (mycophenolate and AZA) and has proven to be equally efficacious. Some of the most encouraging data centers on using everolimus to decrease CNI exposure, sparing transplant patients from the deleterious effects of CNI-induced nephropathy. While some level 1 evidence has been recently published supporting CNIfree immunosuppressive regimens in kidney transplantation, more literature is needed to further define the benefits of mToR based immunosuppression with everolimus.

The review in brief

\begin{tabular}{|ll}
$\begin{array}{l}\text { Clinical question } \\
\text { Type of review }\end{array}$ & Defining everolimus pharmacologic characteristics and role in SOT \\
Search of the literature & $\begin{array}{l}\text { Nedline search for English-language articles using the following keywords: everolimus, RAD, } \\
\text { RAD001, SDZ RAD, Afinitor, Certican, Xience and Zortress. }\end{array}$ \\
Conclusions & $\begin{array}{l}\text { Everolimus is a viable immunosuppressive agent for use in SOT in combination with other } \\
\text { classically used agents. Potentially the most beneficial use of this agent may be as alternative or } \\
\text { substitute for CNI based regimens. }\end{array}$ \\
\hline Limitations & $\begin{array}{l}\text { Peer-reviewed, randomized controlled trials, while most prevalent in kidney trantion, } \\
\text { remain limited in all SOT populations }\end{array}$ \\
\hline & \\
References
\end{tabular}

1. Sarbassov DD, Ali SM, Sabatini DM. Growing roles for the mTOR pathway. Curr Opin Cell Biol 2005; 17: 596-603

2. Hudes GR. Targeting mTOR in renal cell carcinoma. Cancer 2009; 115(10 Suppl): 2313-20

3. Kukreja N, Onuma Y, Serruys PW. Xience V everolimus-eluting coronary stent. Expert Rev Med Devices 2009; 6: 219-29

4. Butt M, Connolly D, Lip GY. Drug-eluting stents: a comprehensive appraisal. Future Cardiol 2009; 5: 141-57

5. Dunn C, Croom KF. Everolimus: a review of its use in renal and cardiac transplantation. Drugs 2006; 66: 547-70

6. Sedrani R, Cottens S, Kallen J, Schuler W. Chemical modification of rapamycin: the discovery of SDZ RAD. Transplant Proc 1998; 30: 2192-4

7. Schuler W, Sedrani R, Cottens S, Haberlin B, Schulz M, Schuurman HJ, et al. SDZ RAD, a new rapamycin derivative: pharmacological properties in vitro and in vivo. Transplantation 1997; 64: 36-42 
8. Kirchner GI, Meier-Wiedenbach I, Manns MP. Clinical pharmacokinetics of everolimus. Clin Pharmacokinet 2004; 43: 83-95

9. Mahalati K, Kahan BD. Clinical pharmacokinetics of sirolimus. Clin Pharmacokinet 2001; 40: 573-85

10. Kovarik JM, Kahan BD, Kaplan B, Lorber M, Winkler M, Rouilly M, et al. Longitudinal assessment of everolimus in de novo renal transplant recipients over the first post-transplant year: pharmacokinetics, exposure-response relationships, and influence on cyclosporine. Clin Pharmacol Ther 2001; 69: 48-56

11. Neumayer HH, Paradis K, Korn A, Jean C, Fritsche L, Budde K, et al. Entry-into-human study with the novel immunosuppressant SDZ RAD in stable renal transplant recipients. Br J Clin Pharmacol 1999; 48: 694-703

12. Budde K, Neumayer HH, Lehne G, Winkler M, Hauser IA, Lison A, et al. Tolerability and steadystate pharmacokinetics of everolimus in maintenance renal transplant patients. Nephrol Dial Transplant 2004; 19: 2606-14

13. Levy GA, Grant D, Paradis K, Campestrini J, Smith T, Kovarik JM. Pharmacokinetics and tolerability of 40-0-[2-hydroxyethyl]rapamycin in de novo liver transplant recipients. Transplantation 2001; 71: 160-3

14. Kovarik JM, Hartmann S, Figueiredo J, Rordorf C, Golor G, Lison A, et al. Effect of food on everolimus absorption: quantification in healthy subjects and a confirmatory screening in patients with renal transplants. Pharmacotherapy 2002; 22: 154-9

15. Kirchner G, Mueller L, Winkler M, Loss M, Roechte F, Deters M, et al. Long-term pharmacokinetics of the metabolites of everolimus and cyclosporine in renal transplant recipients. Transplant Proc 2002; 34: 2233-4

16. Lorber MI, Ponticelli C, Whelchel J, Mayer HW, Kovarik J, Li Y, et al. Therapeutic drug monitoring for everolimus in kidney transplantation using 12-month exposure, efficacy, and safety data. Clin Transplant 2005; 19: 145-52

17. Starling RC, Hare JM, Hauptman P, McCurry KR, Mayer HW, Kovarik JM, et al. Therapeutic drug monitoring for everolimus in heart transplant recipients based on exposure-effect modeling. Am J Transplant 2004; 4: 2126-31

18. Chan L, Hartmann E, Cibrik D, Cooper M, Shaw LM. Optimal everolimus concentration is associated with risk reduction for acute rejection in de novo renal transplant recipients. Transplantation 2010; 90: 31-7

19. Kovarik JM, Beyer D, Schmouder RL. Everolimus drug interactions: application of a classification system for clinical decision making. Biopharm Drug Dispos 2006; 27: 421-6

20. Kovarik JM, Beyer D, Bizot MN, Jiang Q, Shenouda M, Schmouder RL. Blood concentrations of everolimus are markedly increased by ketoconazole. J Clin Pharmacol 2005; 45: 514-8

21. Kovarik JM, Hartmann S, Figueiredo J, Rouilly M, Port A, Rordorf C. Effect of rifampin on apparent clearance of everolimus. Ann Pharmacother 2002; 36: 981-5

22. Kovarik JM, Hartmann S, Hubert M, Berthier S, Schneider W, Rosenkranz B, et al. Pharmacokinetic and pharmacodynamic assessments of HMG-CoA reductase inhibitors when coadministered with everolimus. J Clin Pharmacol 2002; 42: 222-8

23. Kovarik JM, Kalbag J, Figueiredo J, Rouilly M, Frazier OL, Rordorf C. Differential influence of two cyclosporine formulations on everolimus pharmacokinetics: a clinically relevant pharmacokinetic interaction. J Clin Pharmacol 2002; 42: 95-9

24. Pascual J, Del Castillo D, Cabello M, Pallardo L, Grinyo JM, Fernandez AM, et al. Interaction between everolimus and tacrolimus in renal transplant recipients: a pharmacokinetic controlled trial. Transplantation 2010; 89: 994-1000 
25. King-Biggs MB, Dunitz JM, Park SJ, Kay Savik S, Hertz MI. Airway anastomotic dehiscence associated with use of sirolimus immediately after lung transplantation. Transplantation 2003; 75 : 1437-43

26. Groetzner J, Kur F, Spelsberg F, Behr J, Frey L, Bittmann I, et al. Airway anastomosis complications in de novo lung transplantation with sirolimus-based immunosuppression. J Heart Lung Transplant 2004; 23: 632-8

27. Albano L, Berthoux F, Moal MC, Rostaing L, Legendre C, Genin R, et al. Incidence of delayed graft function and wound healing complications after deceased-donor kidney transplantation is not affected by de novo everolimus. Transplantation 2009; 88: 69-76

28. Eisen HJ, Tuzcu EM, Dorent R, Kobashigawa J, Mancini D, Valantine-von Kaeppler HA, et al. Everolimus for the prevention of allograft rejection and vasculopathy in cardiac-transplant recipients. N Engl J Med 2003; 349: 847-58

29. AA.VV. Cytomegalovirus. Am J Transplant 2004; 4 (Suppl 10): 51-8

30. Micromedex ${ }^{\circledR}$ Healthcare Series, (electronic version). Greenwood Village, Colorado, USA.: Thomson Healthcare, Inc.; 2011

31. Vitko S, Margreiter R, Weimar W, Dantal J, Kuypers D, Winkler M, et al. Three-year efficacy and safety results from a study of everolimus versus mycophenolate mofetil in de novo renal transplant patients. Am J Transplant 2005; 5: 2521-30

32. Lorber MI, Mulgaonkar S, Butt KM, Elkhammas E, Mendez R, Rajagopalan PR, et al. Everolimus versus mycophenolate mofetil in the prevention of rejection in de novo renal transplant recipients: a 3-year randomized, multicenter, phase III study. Transplantation 2005; 80: 244-52

33. Nashan B, Curtis J, Ponticelli C, Mourad G, Jaffe J, Haas T. Everolimus and reduced-exposure cyclosporine in de novo renal-transplant recipients: a three-year phase II, randomized, multicenter, open-label study. Transplantation 2004; 78: 1332-40

34. De Simone P, Carrai P, Precisi A, Petruccelli S, Baldoni L, Balzano E, et al. Conversion to everolimus monotherapy in maintenance liver transplantation: feasibility, safety, and impact on renal function. Transpl Int 2009; 22: 279-86

35. Chan L, Greenstein S, Hardy MA, Hartmann E, Bunnapradist S, Cibrik D, et al. Multicenter, randomized study of the use of everolimus with tacrolimus after renal transplantation demonstrates its effectiveness. Transplantation 2008; 85: 821-6

36. Vitko S, Tedesco H, Eris J, Pascual J, Whelchel J, Magee JC, et al. Everolimus with optimized cyclosporine dosing in renal transplant recipients: 6-month safety and efficacy results of two randomized studies. Am J Transplant 2004; 4: 626-35

37. Tedesco Silva H Jr, Cibrik D, Johnston T, Lackova E, Mange K, Panis C, et al. Everolimus plus reduced-exposure CsA versus mycophenolic acid plus standard-exposure CsA in renal-transplant recipients. Am J Transplant 2010; 10: 1401-13

38. Budde K, Becker T, Arns W, Sommerer C, Reinke P, Eisenberger U, et al. Everolimus-based, calcineurin-inhibitor-free regimen in recipients of de-novo kidney transplants: an open-label, randomised, controlled trial. Lancet 2011; 377: 837-47

39. Vigano M, Tuzcu M, Benza R, Boissonnat P, Haverich A, Hill J, et al. Prevention of acute rejection and allograft vasculopathy by everolimus in cardiac transplants recipients: a 24-month analysis. $J$ Heart Lung Transplant 2007; 26: 584-92

40. Lehmkuhl HB, Arizon J, Vigano M, Almenar L, Gerosa G, Maccherini M, et al. Everolimus with reduced cyclosporine versus MMF with standard cyclosporine in de novo heart transplant recipients. Transplantation 2009; 88: 115-22

41. Gullestad L, Iversen M, Mortensen SA, Eiskjaer H, Riise GC, Mared L, et al. Everolimus with reduced calcineurin inhibitor in thoracic transplant recipients with renal dysfunction: a multicenter, randomized trial. Transplantation 2010; 89: 864-72 
42. Engelen MA, Amler S, Welp H, Vahlhaus C, Gunia S, Sindermann JR, et al. Prospective study of everolimus with calcineurin inhibitor-free immunosuppression in maintenance heart transplant patients: results at 2 years. Transplantation 2011; 91: 1159-65

43. Levy G, Schmidli H, Punch J, Tuttle-Newhall E, Mayer D, Neuhaus P, et al. Safety, tolerability, and efficacy of everolimus in de novo liver transplant recipients: 12- and 36-month results. Liver Transpl 2006; 12: 1640-8

44. Gomez-Camarero J, Salcedo M, Rincon D, Lo Iacono O, Ripoll C, Hernando A, et al. Use of everolimus as a rescue immunosuppressive therapy in liver transplant patients with neoplasms. Transplantation 2007; 84: 786-91

45. Snell GI, Valentine VG, Vitulo P, Glanville AR, McGiffin DC, Loyd JE, et al. Everolimus versus azathioprine in maintenance lung transplant recipients: an international, randomized, double-blind clinical trial. Am J Transplant 2006; 6: 169-77

46. Hoyer PF, Ettenger R, Kovarik JM, Webb NJ, Lemire J, Mentser M, et al. Everolimus in pediatric de nova renal transplant patients. Transplantation 2003; 75: 2082-5

47. Pape L, Ahlenstiel T, Ehrich JH, Offner G. Reversal of loss of glomerular filtration rate in children with transplant nephropathy after switch to everolimus and low-dose cyclosporine A. Pediatric Transplantation 2007; 11: 291-5 